\title{
Analisis Suhu Permukaan Laut untuk Penentuan Daerah Potensi Ikan Menggunakan Citra Satelit Modis Level 1B (Studi Kasus: Selat Bali)
}

\author{
Latifatul Zahroh, Bangun Muljo Sukojo \\ Jurusan Teknik Geomatika, Fakultas Teknik Sipil dan Perencanaan, Institut Teknologi Sepuluh \\ Nopember (ITS) \\ Jl. Arief Rahman Hakim, Surabaya 60111 Indonesia \\ e-mail: bangunms@gmail.com
}

\begin{abstract}
Abstrak-Selat Bali merupakan perairan yang terletak diantara Pulau Jawa dan Pulau Bali yang merupakan daerah potensial untuk bidang perikanan. Karena letaknya yang dipengaruhi oleh Laut Jawa dan Samudera Hindia ini menyebabkan perairan di Selat Bali mengandung banyak nutrien yang merupakan sumber makanan bagi ikan. Untuk mengoptimalkan potensi tersebut perlu dilakukan pengembangan teknologi penginderaan jauh salah satunya dengan mengidentifikasi suhu permukaan laut (SPL). Suhu optimum antara $20^{\circ} \mathrm{C}$ sampai $30^{\circ} \mathrm{C}$. SPL didapatkan dari pengolahan data dari citra satelit MODIS. Pengolahan SPL dilakukan menggunakan algoritma Minnet 2001. Hasil dari penelitian ini menunjukkan bahwa pada bulan April 2012 dengan rentang suhu antara $20^{\circ} \mathrm{C}$ sampai $29,94^{\circ} \mathrm{C}$. Namun terjadi penurunan signifikan pada bulan Oktober 2012 karena menurunnya persebaran suhu yang sesuai dengan kriteria daerah potensi ikan yaitu dengan rentang suhu antara $20,06^{\circ} \mathrm{C}$ sampai $29,34^{\circ} \mathrm{C}$. Sedangkan pada bulan Mei 2013 SPL cenderung tinggi yaitu pada rentang suhu antara $23,67^{\circ} \mathrm{C}$ sampai $29,97^{\circ} \mathrm{C}$.
\end{abstract}

Kata Kunci-Daerah Potensi Ikan, MODIS, suhu permukaan laut

\section{PENDAHULUAN}

$\mathrm{S}$ ELAT Bali merupakan perairan yang relatif sempit (sekitar 960 mil atau $1776 \mathrm{~km}$ ) menghubungkan Laut Flores dan Selat Madura di utara dan Samudera Hindia dibagian selatan. Mulut bagian utara sekitar satu mil dan merupakan perairan yang dangkal (kedalaman sekitar 50 meter), sedangkan di bagian selatan memiliki wilayah yang luas yaitu sekitar 28 mil $(51,8 \mathrm{~km})$, merupakan perairan yang dalam. Selat ini adalah salah satu selat yang memiliki fungsi dan peranan penting dalam transportasi laut di Indonesia, yaitu sebagai penghubung antara Pulau Jawa dan Pulau Bali. Selat Bali memiliki potensi yang cukup tinggi di bidang perikanan tangkap khususnya perikanan lemuru (Sardinella lemuru) dan masuk dalam bagian WPP (Wilayah Pengelolaan Perikanan) 573.

Teknologi penginderaan jauh atau remote sensing dapat digunakan untuk menentukan posisi daerah potensi ikan dengan mengidentifikasi beberapa indikator tingkat kesuburan perairan dan kelimpahan makan bagi ikan. Beberapa parameter yang sering dijadikan indikator tersebut adalah suhu permukaan laut. Suhu permukaan laut dapat diestimasi dengan teknik penginderaan jauh, dimana saat ini algoritma SPL tingkat akurasinya lebih dari $70 \%$ [3].

Salah satu instrumen yang dapat digunakan untuk mendeteksi SPL yaitu citra satelit MODIS. Citra satelit MODIS dipilih karena memiliki luasan sapuan mencapai $2330 \mathrm{~km}$ dengan resolusi temporal 1 hari, sehingga data yang ada lebih beragam dan lebih mudah dilakukan pemilihan kawasan yang bebas awan. Untuk mendapatkan SPL dilakukan dengan algoritma dari kombinasi band yang ada pada citra satelit MODIS. Pada algoritma suhu permukaan laut menggunakan algoritma Minnet [5]. Algoritma tersebut menggunakan nilai kecerahan suhu dari band 31 dan 32 .

\section{METODOLOGI PENELITIAN}

\section{A. Lokasi Penelitian}

Lokasi penelitian ini terletak di Selat Bali yaitu pada koordinat adalah $8^{0} 24^{\prime} 0$ " ' LS sampai 8 ${ }^{0} 54^{\prime} 0^{\prime \prime}$ LS dan $114^{0} 30^{\prime} 0^{\prime \prime}$ BT sampai $115^{0} 12^{\prime} 0^{\prime \prime}$ BT.

\section{B. Data dan Peralatan}

a. Data

Data yang digunakan dalam penelitian ini yaitu:

1. Citra Modis level 1B pada koordinat $8^{0} 24^{\prime} 0^{\prime \prime}$ LS sampai 8054'0" LS dan 114030'0" BT sampai $115^{0} 12^{\prime} 0^{\prime}$ " BT pada bulan April dan Oktober tahun 2012 serta bulan Mei tahun 2013 yang didapat dari website http://ladsweb.nascom.nasa.gov/

2. Data insitu berupa konsentrasi klorofil-a dan suhu permukaan laut dari Balai Penelitian dan Observasi Laut Jembrana Bali

3. Data pendukung lainnya seperti data angin didapatkan dari ECMWF

b. Peralatan

Peralatan yang digunakan dalam penelitian ini yaitu:

1. Perangkat lunak (software) yang digunakan dalam pengerjaan penelitian ini antara lain:

a. SeaDAS 7.3.1 untuk mengolah data citra Modis Level 1B

b. ArcGIS 10.3 untuk proses klasifikasi dan layouting peta

c. Ocean Data View 4 untuk konversi data NetCDF menjadi data xls

d. Surfer 11 untuk pengolahan data gelombang 


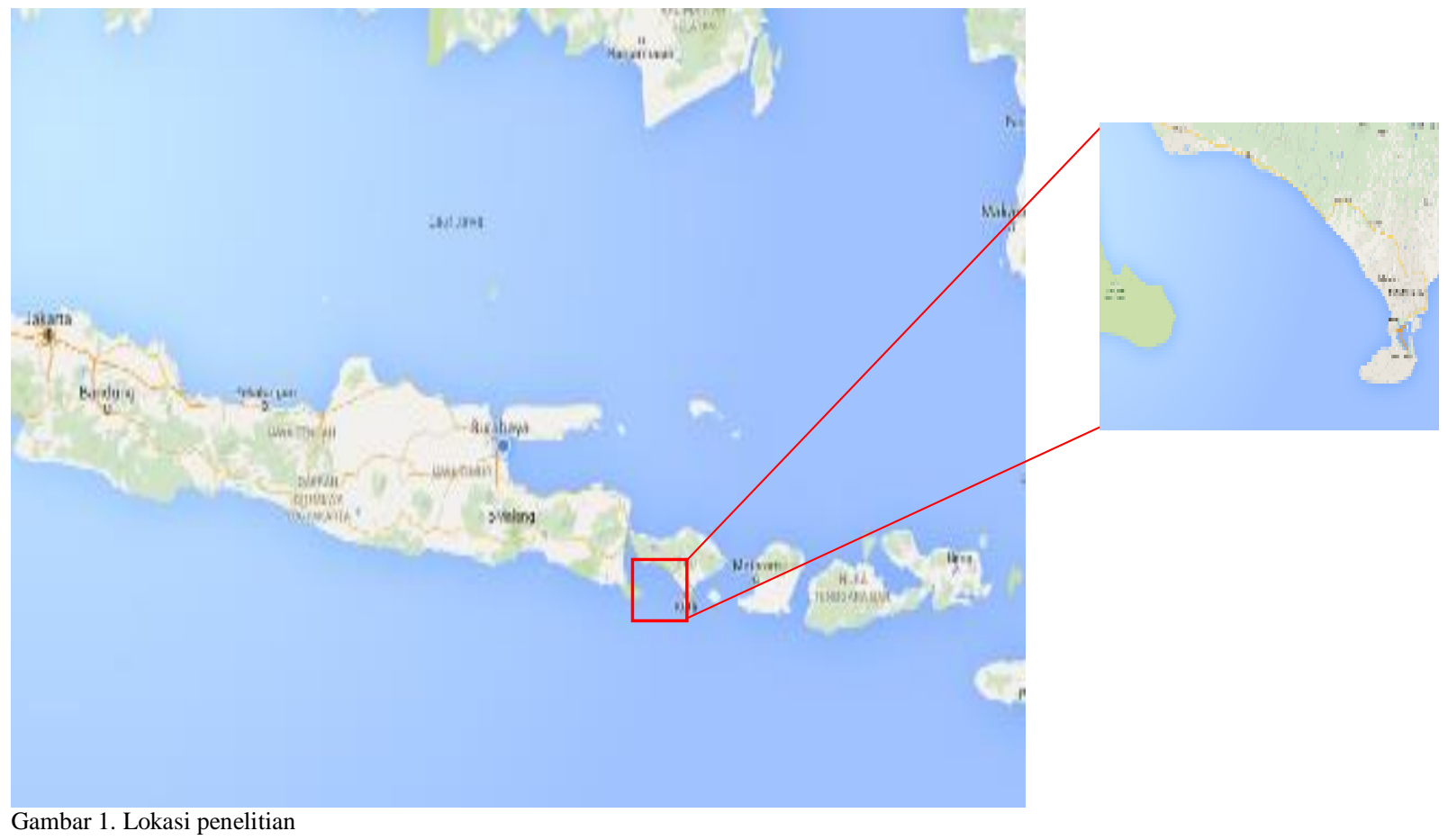

(Sumber: Google Maps, 2015) [4]

\section{Tahap Pengolahan Data}

Citra satelit MODIS yang telah didapat dari website http://ladsweb.nascom.nasa.gov/ kemudian digeoreference untuk memberikan sistem proyeksi pada citra sekaligus memasukkan data geolocation yang dimiliki citra satelit MODIS. Untuk memastikan bahwa proses tersebut sudah sesuai dilakukan perhitungan Strength of Figure (SoF) dan Root Mean Square Error (RMSE). Selanjutnya dilakukan konversi Emmisive ke Brightness Temperature pada band 31 dan 32 yang akan digunakan untuk pemrosesan algoritma Minnet [5]. Untuk membedakan antara daratan dan perairan digunakan algoritma Normalized Different Water Index (NDWI) dengan menggunakan rumus sebagai berikut:

$$
N D W I=\frac{(\text { Band } 4-\text { Band } 2)}{(\text { Band } 4+\text { Band } 2)}
$$

Suatu daerah dikatakan sebagai perairan jika nilai $N D W I$ lebih dari 0. Sedangkan untuk menghilangkan data pada daerah yang tertutup awan dilakukan cloud masking [7] dengan rumus sebagai berikut:

$$
(\operatorname{Ref} 3 \geq 0,2) * 0+(\operatorname{Ref} 3 \leq 0,2) * 1
$$

Algoritma Minnet [5] yang digunakan pada penelitian ini adalah sebagai berikut:

$$
S P L=-0,0024+3,53 \mathrm{~Tb}_{31}-2,52 \mathrm{~Tb}_{32}-0,582-273
$$

Dimana $S P L$ adalah suhu permukaan laut $\left({ }^{\circ} \mathrm{C}\right), \mathrm{TB}_{31}$ dan $\mathrm{TB}_{32}$ menyatakan nilai Brightness Temperature dari band 31 dan band 32 .

Kemudian hasil dari penerapan algoritma tersebut dilakukan klasifikasi untuk mendapatkan daerah potensi ikan dengan nilai SPL berkisar antara $20^{\circ} \mathrm{C}$ sampai $30^{\circ} \mathrm{C}$ yang merupakan suhu optimum bagi perkembangan fitoplankton di perairan [1].

Untuk memvalidasi keakuratan dari SPL yang telah didapatkan, dilakukan uji korelasi data citra hasil penerapan algoritma Minnet [5] dengan data insitu.

\section{HASIL DAN PEMBAHASAN}

\section{A. Perbaikan Citra}

Berdasarkan Gambar 2 didapatkan nilai SoF yang mendekati 0 yaitu sebesar 0,0012 . Hal tersebut menunjukan desain jaring tersebut memiliki kekuatan jaring yang bagus. Sedangkan nilai $R M S E$ yang terlihat pada Tabel 1 menunjukkan nilai yang bagus karena memiliki nilai kurang dari 1 piksel dan mendekati 0 .

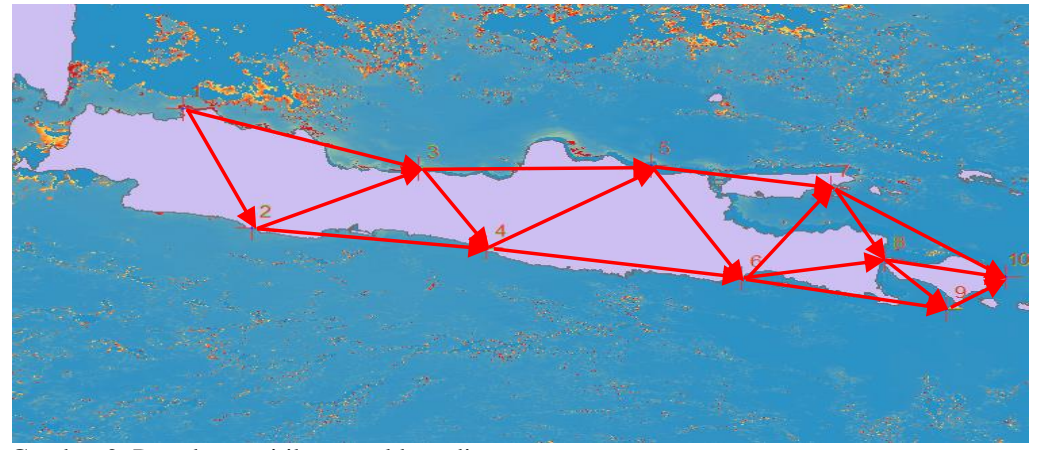

Gambar 2. Persebaran titik sampel koordinat 
Tabel 1.

Nilai kesalahan RMS/RMSError

\begin{tabular}{ccc}
\hline \hline No & Tanggal & RMSE (Piksel) \\
\hline 1 & April 2012 & 0.748 \\
2 & Oktober 2012 & 0.225 \\
3 & Mei 2013 & 0.416 \\
\hline \hline
\end{tabular}

B. Persebaran Suhu Permukaan Laut

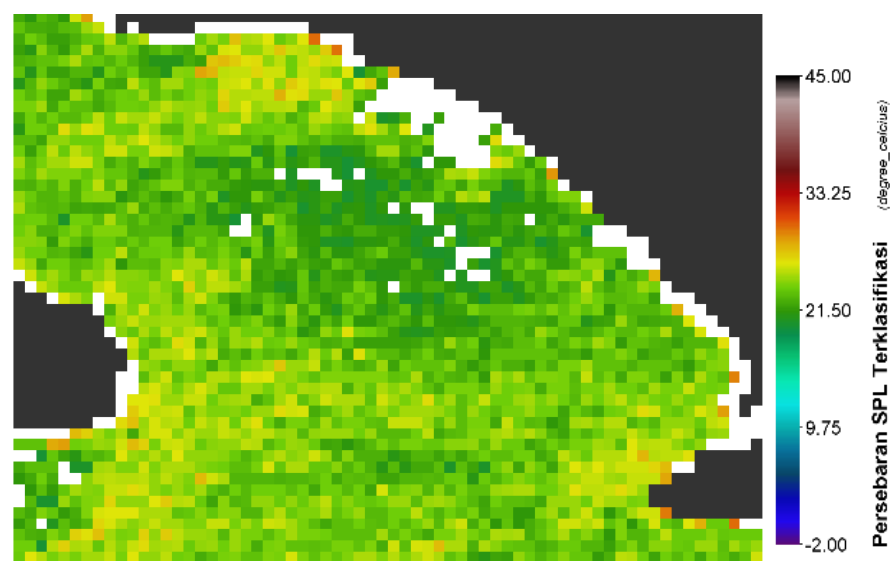

Gambar 3. Peta persebaran SPL April 2012

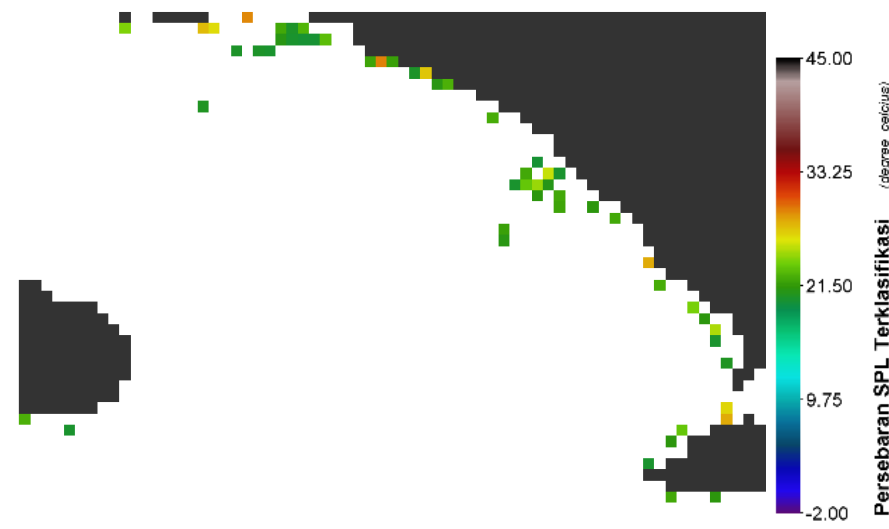

Gambar 4. Peta persebaran SPL Oktober 2012

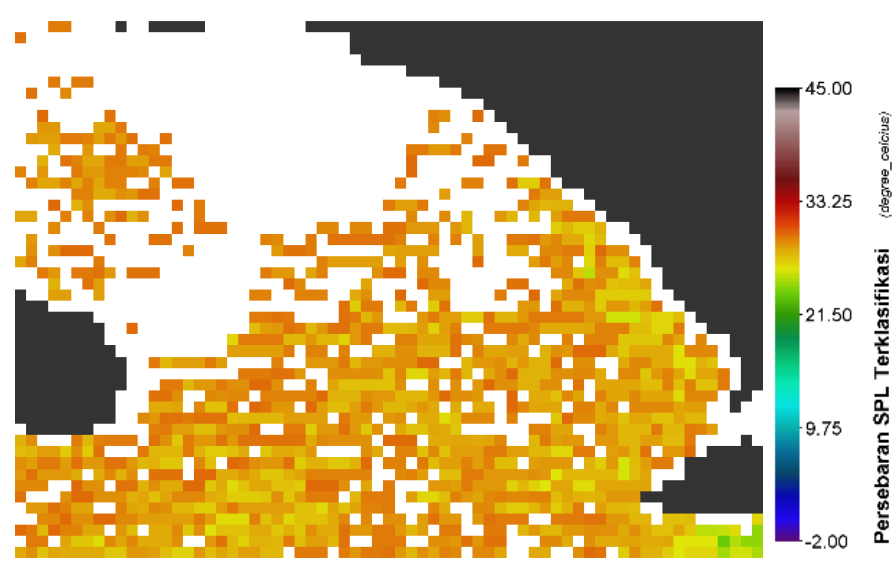

Gambar 5. Peta persebaran SPL Mei 2013

Berdasarkan hasil klasifikasi SPL didapatkan persebaran SPL seperti yang terlihat pada Gambar 3, 4 dan 5. Persebaran SPL pada bulan April 2012 cenderung merata, sedangkan pada bulan Oktober yang memiliki SPL yang cenderung rendah hanya memiliki sedikit daerah persebaran SPL yang terklasifikasi. Hal tersebut terjadi akibat adanya periode monsun Australia, wilayah bumi bagian selatan lebih dingin dibandingkan dengan bumi bagian utara. Matahari saat itu berada di bumi bagian utara sehingga atmosfernya cenderung lebih hangat, hal ini diikuti oleh menghangatnya SPL di bumi bagian utara [2]. Adapun interval dari nilai minimum dan maksimum $S P L$ terklasifikasi seperti dapat dilihat pada Tabel 2.

Tabel 2.

Nilai minimum dan maksimum SPL terklasifikasi

\begin{tabular}{ccc}
\hline \hline Tanggal & $\begin{array}{c}\text { Nilai Minimum } \\
\left({ }^{\circ} \mathbf{C}\right)\end{array}$ & $\begin{array}{c}\text { Nilai Maksimum } \\
\left({ }^{\circ} \mathbf{C}\right)\end{array}$ \\
\hline April 2012 & 20,00 & 29.94 \\
Oktober 2012 & 20,06 & 29.34 \\
Mei 2013 & 23,67 & 29.97 \\
\hline
\end{tabular}

\section{Hasil Korelasi Data Citra dengan Data Lapangan}

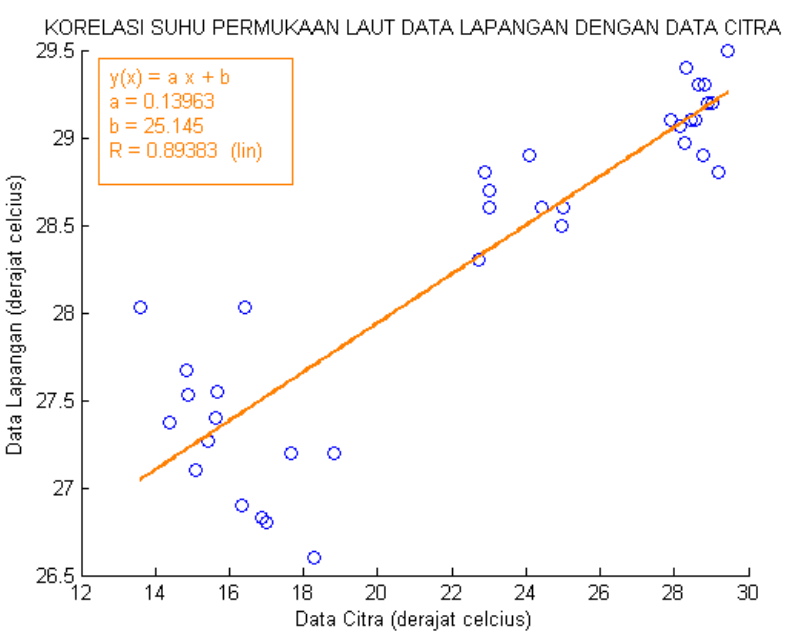

Gambar 13. Grafik korelasi SPL data lapangan dengan data citra

Berdasarkan Gambar 13 didapatkan nilai korelasi SPL sebesar 0,89383 dan regresi linier sederhana mendapatkan persamaan $\mathrm{Y}=0,13363 \mathrm{X}+25,145$. Berdasarkan hasil tersebut maka dapat disimpulkan bahwa nilai SPL hasil pengolahan dengan data lapangan memiliki korelasi yang kuat [6]. Sehingga nilai SPL citra memiliki pengaruh sebesar $89,383 \%$ terhadap SPL di lapangan.

\section{KESIMPULAN/RINGKASAN}

Berdasarkan hasil dan pembahasan tersebut dapat ditarik kesimpulan yaitu:

a. Berdasarkan persebaran SPL didapatkan pada bulan April 2012 kisaran suhu antara $20^{\circ} \mathrm{C}$ sampai $29,94^{\circ} \mathrm{C}$, pada bulan Oktober 2012 kisaran suhu antara $20,06^{\circ} \mathrm{C}$ sampai $29,34^{\circ} \mathrm{C}$ dan pada bulan Mei 2013 kisaran suhu antara $23,67^{\circ} \mathrm{C}$ sampai $29,97^{\circ} \mathrm{C}$.

b. Perubahan SPL terjadi akibat adanya periode monsun Australia, wilayah bumi bagian selatan lebih dingin dibandingkan dengan bumi bagian utara.

c. Data SPL citra dengan data lapangan memiliki korelasi yang kuat dengan nilai korelasi sebesar 0,89383 dengan persamaan Regresi Linier Sederhana $\mathrm{Y}=0,13363 \mathrm{X}+$ 25,145 .

Adapun saran-saran dari berbagai kendala yang dialami penulis adalah sebagai berikut: 
a. Diperlukan pemilihan waktu (tanggal) dari citra yang tepat untuk meminimalisir kesalahan akibat awan atau efek atmosfer.

b. Untuk mendapatkan daerah potensi ikan yang lebih akurat disarankan menggunakan algoritma SPL yang sesuai dengan area studi serta disarankan untuk menambahkan parameter lainnya seperti parameter konsentrasi klorofil-a, arus dan tinggi muka air laut.

\section{LAMPIRAN}
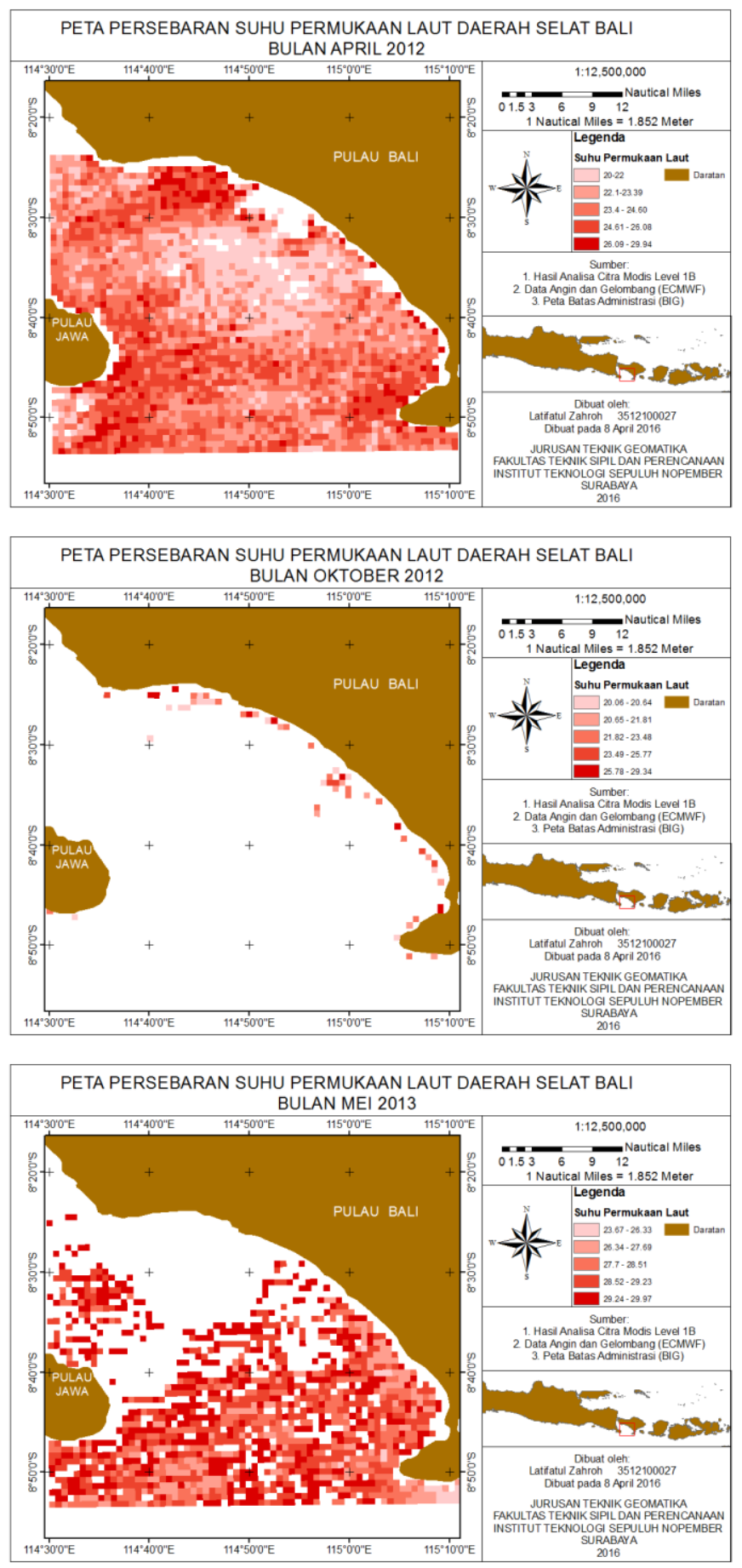

\section{UCAPAN TERIMA KASIH}

Penulis L.Z. mengucapkan terima kasih kepada Direktorat Pendidikan Tinggi, Departemen Pendidikan dan Kebudayaan Republik Indonesia yang telah memberikan dukungan finansial melalui Beasiswa Bidik Misi tahun 2012-2016 dan juga kepada Kepala Balai Penelitian dan Observasi Laut Jembrana Bali yang telah memberikan dukungan berupa bantuan data insitu untuk penelitian ini.

\section{DAFTAR PUSTAKA}

[1] Effendi, H. (2003). Telaah Kualitas Air: Bagi Pengelolaan Sumberdaya dan Lingkungan Perairan. Bogor: Jurusan Manajemen Sumberdaya Perairan Fakultas Perikanan dan Ilmu Kelautan Institut Pertanian Bogor.

[2] Habibie, M. N., \& Nuraini, T. A. (2014). Karakteristik dan Tren Perubahan Suhu Permukaan Laut di Indonesia Periode 1982-2009. Jurnal Meteorologi dan Geofisika Volume 15 Nomor 1, 37-49.

[3] Indrayani, Mallawa, A., \& Zainuddin, M. (2012). Penentuan Karakteristik Habitat Daerah Potensi Ikan Pelagis Kecil Dengan Pendekatan Spasial Di Perairan Sinjai. Makassar: Fakultas Ilmu Kelautan dan Perikanan, Universitas Hasanuddin.

[4] Maps, G. (2015, Desember 27). Google Maps. Dipetik Desember 14, 2015, dari Google Maps: https://www.maps.google.co.id/

[5] Suwargana, N., \& Arief, M. (2004). Penentuan Suhu Permukaan Laut dan Konsentrasi Klorofil Untuk Pengembangan Model Prediksi Fishing Ground Dengan Menggunakan Data Modis. Jurnal Penginderaan Jauh dan Pengolahan Data Citra Digital Vol. 1 No. 1, 1-13.

[6] Trijayanto, D. P. (2015). Analisa Persebaran Potensi Ikan Dengan Menggunakan Data Modis, VIIRS dan Insitu (Studi Kasus: Selat Madura). Surabaya: Jurusan Teknik Geomatika-FTSP ITS.

[7] Xiong, X., Salomonson, V. V., Kuyper, J., Tan, L., Chiang, K., Sun, J., \& Barnes, W. L. (2016). Status of the MODIS Level 1B Algorithms and Calibration Tables. International Geoscience and Remote Sensing Symposium (IGARSS), 2231-2234. 